\title{
THE HYDROGEN BOMB EXPERIMENTS AND INTERNATIONAL LAW
}

\author{
EMARUEL MARGOLISi
}

THE hydrogen bomb shot of March 1, 1954-much more so than its predecessor of November 1952-was a shot heard 'round the world. Not unlike certain of the physical results of this thermonuclear experiment, the political "cloud" and the legal "fallout" which the explosion produced were not anticipated fully.

Serious injury of a number of Japanese fishermen, coupled with contamination of considerable quantities of fish, caused by the fallout of radioactive ash over a large area in the Pacific Ocean, had an enormous impact on public opinion throughout the world. At the same time, these events have given rise to a sudden concern over some of the legal problems surrounding the thermonuclear weapon.1 Thus, the weapon itself has been denounced as "barbarous" and "inhuman," as being in disregard of the historic distinction between combatants and noncombatants, and as a contravention of the Geneva Convention of $1925 .^{2}$ Even the conducting of experiments with such weapons has been vigorously attacked by statesmen and by scientists. ${ }^{3}$

Other legal issues were raised in the United Nations. The inhabitants of the Marshall Islands petitioned the U.N. Trusteeship Council for an end to

$\dot{\bar{T}}$ Ph. $\dot{D}$., Member of the American Society of International Law.

1. It is rather surprising how little attention this aspect of the hydrogen bomb experiments has received in the United States.

2. See speech by W. Harvey Moore, General Secretary of the International Law Association, before the 1954 Conference of the Association in Edinburgh, N.Y. Times, Aug. 10, 1954, p. 9, col. 2.

3. For example, see Jawaharlal Nehru's speech before the House of the People (lower chamber of the Indian Parliament), N.Y. Times, April 3, 1954, p. 1, col. 1; the speech of India's V.K. Krishna Mfenon before the U.N. Trusteeship Council, N.Y. Times, July 10, 1954, p. 1, col. 7; and speech of James Barrington, Burma's representative in the U.N. General Assembly, N.Y. Times, Oct. 2, 1954, p. 4, col. 7. Afore than 100 members of the British Labor Party signed a motion demanding that the tests be stopped. The Times (London), March 31, 1954, p. 8, col. 2. Dr. Hideki Yukawa, Japanese nuclear physicist and Nobel Prize winner, characterized the experiments as "atomic energy versus mankind." N.Y. Times, April 16, 1954, p. 7, col. 3. See also Albert Schweitzer's letter to the London Daily Herald, reprinted in 10 BuLn. Atosr. Scresmists 339 (1954); letter from Alexander Haddow, Director of the Chester Beatty [Cancer] Research Institute, to the The Times (London), March 30, 1954, p. 7, col. 5; and letter from Dr. Arortimer Camiel, N.Y. Times, April 16, 1954, p. 20, col. 6. 
the tests or, failing that, for guarantees of strict safety measures. ${ }^{4}$ In response to this petition, the Indian and Soviet representatives on the Council introduced resolutions ${ }^{5}$ calling for immediate cessation of the experiments, on the grounds that they violated the Administering Authority's rights and duties under the U.N. Charter and the Trusteeship Agreement for the Former Japanese Mandated Islands. ${ }^{6}$

But still more basic legal problems are posed by these experiments, problems which have received less public attention. These concern the international law principle of freedom of the seas and its attendant corollaries, freedom of navigation (of both the sea and the air), and freedom from interference with the lawful pursuit of maritime industries (fishing, transport, and the like). Finally, the interesting question of pollution of international waters and air space has been cast at once into a different and a compelling form.

There is every reason to believe that the Pacific experiments will continue ? and that the legal issues which they present will persist. Opponents of the hydrogen bomb may be expected to raise these issues with increasing frequency and intensity as the armaments race progresses. It is extremely important to American prestige in the world community that the case against continuation of these tests in the Pacific Proving Grounds be carefully examined.

\section{The Broader Issue: Freedon of the Seas \\ The Facts}

The first atomic weapons tests conducted by the United States outside its own territorial limits took place on Bikini atoll in the Marshall Islands in 1946. The following year, three island groups, the Marshalls, the Carolines, and the Marianas, were placed under United Nations trusteeship, with the United States as Administering Authority. ${ }^{8}$ Upon United States insistence, the entire territory-comprising ninety-eight distinct islands and island units with a combined land area of 846 square miles, spread over some three million square miles of ocean-was set up as "strategic" under Article 82 of the U.N. Charter. ${ }^{\circ}$ Article 13 of the Trusteeship Agreement establishes the right of the

4. The petition was prompted by radioactive fallout on several hundred Marshallese who were "suffering in various degrees from 'lowering of the blood count,' burns, natsea and the falling off of hair from the head, and whose complete recovery no one can promise with certainty." Petition from the Marshallese People Concerning the Pacific Islands, U.N. Doc. No. T/Pet. 10/28 (1954).

5. U.N. Doc. No. T/C.2/L.101. (1954) (Soviet resolution); and U.N. Doc. No. T/C. 2/L.104 (1954) (Indian resolution).

6. Trusteeship Agreement for the Former Japanese Mandated Islands, July 18, 1947, 61 Stat. 3301, T.I.A.S. No. 1665 (cited hereinafter as Trusteeship AgreEment).

7. See statement of Admiral Lewis L. Strauss, Chairman of the U.S. Atomic Energy Commission, N.Y. Times, Sept. 10, 1954, p. 1, col. 3.

8. See Trusteeship AgreEnent.

9. See Goodrich \& Hambro, Charter of the United Nations, $452-53$ (2d ed. 1949). This is the only "strategic" trust territory in existence. 
Administering Authority to close any areas of this "strategic" territory" at any time "for security reasons."

On December 2, 1947, the U.S. Atomic Energy Commission (AEC) announced that Eniwetok atoll in the Marshall Islands had been selected as a proving ground for routine experiments in atomic weapons. Its inhabitants were resettled on Ujelang atoll. ${ }^{10}$ According to the AEC, Eniwetok was chosen because it had the fewest inhabitants to be cared for, 145, "it is isolated and there are hundreds of miles of open seas in the direction in which winds might carry radioactive particles." 11 Eniwetok and its surrounding waters were first established as a "danger area" on December 30, 1947, for a period of one year. ${ }^{12}$ The warning area was established "until further notice" toward the close of $1948 .{ }^{13}$ It was the AEC's view that the larger test detonations could not be carried out within continental United States with the requisite degree of safety ${ }^{14}$ - the largest proving ground in this country being a f 10 square mile tract in Nevada.

In preparation for the thermonuclear test series of March-April 1954, the Pacific Proving Grounds were extended to include Bikini atoll once again in order "to accommodate the rapidly expanding program of developing and testing new and improved nuclear weapons," and "because of the limited size of Eniwetok."'15 Shortly after this expansion, the United States Navy Hydrographic Office advised that "the danger area surrounding Eniwetok and Bikini atolls, dangerous to all ships, aircraft, and personnel entering it, has been enlarged and redefined ....." The new area formed a rectangle of open sea around the two atolls of approximately 50,000 square miles. ${ }^{17}$

10. The 160 inhabitants of Bikini had already been removed from Bikini prior to the 1946 tests and placed on Rongerik atoll; they were eventually relocated on Kili Island in the southern Miarshalls. NAvy Dep't, Trust Territory of the Pactfic Islazids 3 (1948); Petition from the Mrarshallese People Concenting the Pacific Islands, U.N. Doc. No. T/Pet.10/28 (1954).

11. AEC Press Release No. 70, Dec. 1, 1947.

12. AEC Press Release No. 77, Dec. 30, 1947. The area was delineated as follows: 'Beginning with a point at $10^{\circ}-15^{\prime}$ North latitude and $160^{\circ}-35^{\prime}$ ' East longitude, north along the meridian of $160^{\circ}-35^{\prime}$ East longitude to a point at $12^{\circ}-45^{\prime}$ North latitude, $160^{\circ}-35^{\prime}$ East longitude thence East along the parallel of $12^{\circ}-45^{\prime}$ North latitude to a point at $12^{\circ}-45^{\prime}$ North latitude and $163^{\circ}-55^{\prime}$ East longitude, thence south along the meridian of $163^{\circ}-55^{\prime}$ East longitude to a point at $10^{\circ}-15^{\prime}$ North latitude and $163^{\circ}-55^{\prime}$ East longitude, thence west to the point of beginning."

13. AEC Press Release No. 147, Dec. 15, 1948.

14. 13 AEC Searann. Rep. 81 (1953).

15. AEC Press Release No. 478, April 2, 1953. See also letter dated April 2, 1953 from Representative of the United States Addressed to Secretary-General Relating to Trust Territory of the Pacific Islands, U.N. Dac. No. S/2978 (1953).

16. Letter from Shelby Thompson, Acting Director, Division of Information Services, AEC, to Emanuel Margolis, Aug. 9, 1954, on file in Yale Law Library (hercinafter cited as Thompson Letter), quoting U.S. Navy Hydrographic Office, Marimer's Notice No. 21, p. 971, art. 2716, item 1, MIay 23, 1953.

17. It included "that area of about 150 miles by 335 miles centercd midway betwesn Eniwetok and Bikini atolls...." Ibid. 
On April 3, 1954, following the exposure of a number of Japanese fishermen to radiation and the confiscation of radioactive fish by the Japanese Government, ${ }^{18}$ the "danger area" was expanded several times in magnitude, so that it encompassed some 400,000 square miles. ${ }^{10}$

\section{The Laze}

"International law had its origin in the attempt to set $" p$ some law" which would be respected and observed upon the seas, where no nation had right of dominion and where lay the free highweyys of the world."

-Woodrow Wilson 20

During the late middle ages, claims of sovereignty over portions of the open sea were made by many states including the Republics of Venice and Genoa, Portugal, Spain, Sweden, Denmark, and England. ${ }^{21}$ The primary motivation for these claims appears to have been a desire on the part of the maritime powers to develop and maintain trading monopolies. ${ }^{22}$ Their claims of sovereignty assumed such forms as levying tolls upon foreign ships, proscribing fisheries to foreigners, and, in certain instances, prohibiting foreign shipping altogether. Concomitant to such claims, however, there usually ran an obligation of the maritime power to police his sovereign sea against piracy.

It is difficult to locate, in point of time, the shift in international usage and diplomacy from the doctrine of sovereignty over the seas to the principle of freedom of the seas. Some scholars trace its beginnings as far as the twelfth century..$^{23}$ But the first clear, forceful and successful application of the principle is generally attributed to Queen Elizabeth. ${ }^{24}$ And the first scholarly statement of freedom of the seas as a principle of law is found in the Mar: Liberum of Hugo Grotius, published in $1609 .^{25}$ Since the sea could not be

18. See text at notes $45-53$ infra for a fuller description of these facts.

19. The new area was "to include a sector centered at $12^{\circ} 00^{\prime} \mathrm{N}$., and $164^{\circ} 00^{\prime} \mathrm{E}$., extending clockwise from $240^{\circ}$ true to $95^{\circ}$ true; from the center out to a distance of 450 nautical miles." Thompson Letter, quoting U.S. Navy Hydrographic Office, Mariner's Notice, No. 14, p. 1685, April 3, 1954.

20. Address before joint session of Congress, April 2, 1917. 55 Cong. Rec. 103 (1917).

21. See Hall, International LaW, 179-80 (8th ed., Higgins, 1924); 1 Grbil, Lk: Droit International Public de la Mer 129-33 (1932).

22. Smith, Law and Custom of the Sea 43-44 (2d ed. 1950).

23. See Valéry, Le Pape Alexandre III et la Liberté des Mers, 14 Revue Génténde: de Droit International Public 240 (1907). The author cites a letter of Pope Alexander III to the Genoese, dated Oct. 11,1169, arguing in favor of the principle of freedom of the seas. However, Valéry concedes the complete ineffectiveness of this gesture at the time. Id. at $241,250$.

24. In the disputes with Portugal and Spain which came to a head in the year 1580 over a voyage by Drake, the English position was based explicitly on principles of natural law. In the words of Queen Elizabeth: "The use of the sea and air is common to all; neither can any title to the ocean belong to any people or private man, forasmuch as neither nature nor regard of the public use permitteth any possession thereof." Quoted in SMrn, op. cit. supra note 22 , at 44 .

25. Its first English translation by Magoffin in 1916 bore the telling title: TuE FrEt- 
subjected to effective occupation or possession, Grotius argued, it was by nature free of the sovereign control of any single state or group of states. Although they met with considerable opposition throughout the remainder of the seventeenth century, ${ }^{26}$ Grotius' ideas gradually gained the adherence and support of the leading maritime states. $2 \pi$ By the beginning of the eighteenth century, ${ }^{28}$ freedom of the open seas was fairly well establisherl in the law 20 and practices of nations. By the nineteenth century it was axiomatic. In the twentieth it came to occupy a prominent place in Vilson's "Fourteen Points" and the "Atlantic Charter." 30 In its modern form as a rule of international law, freedom of the seas is said to subsume four distinct "freedoms":

don of the Seas ("Or, The Right Which Belongs to the Dutch to T.he Part i: THE EAST INDIAN TRADE").

26. See, e.g., Gentill, Advocatio Hispanica (1613); Selden, Minae cluuslus seu DE Doxrmino Maris (1635). Brierly describes this period: "As yet there was nu general hostility to the existence of sovereignty over the sea; what the nations wanted, and what they gradually succeeded in establishing, was freedom of navigation, which was quite consistent with the existence of sovereignty ...." ERIERLY, The Law of Xarions 224 (4th ed. 1949). Even Great Britain herself, at this time concerned with monopolizing certain fisheries in her adjacent seas, turned a hostile ear to the Grotian thesis, and attempted to revive her fading claims to sovereignty in the "British Seas." Sarıtr, op. cif. supra note 22 , at 43 .

27. The issue "was settled in the seventeenth century by the political decline of states putting forward such claims [of sovereignty]; by the coordination of Eritish and Dutch policies and by the ascendancy of the English fleet .... . This fleet, once it had become de facto mistress of the high seas, had no longer any interest in supporting Selden's uutdated arguments." U.N. Secretariat, Regime of the High Scas, U.N. Doc. No. A/CN.4/32, at 3 (1950) (Memorandum to Int'l Law Comm'n). But $c f$. declaration by the law officers of the British Crown in 1851: "We consider it to be settled by the highest authorities of the English Law that the Dominion of the whole Sea which surrounds England belongs to the Crown ...." Quoted in 2 Smith, Great Britam aNd tae Law of Nations 113 (1935).

28. Gidel contends that the principle of freedom of the seas has been "an unchallenged principle of international public maritime law" since the end of the seventeenth century. 1 GidEL, op. cit. supra note 21, at 199. See also François, Report on the High Seas, U.N. Doc. No. A/CN.4/17, at 3 (1950) (Report to Int'l Law Comm'n). Nevertheless, throughout the eighteenth century and part of the nineteenth, vessels entering waters regarded by Great Britain as "British Seas" had to salute the British flag. See Hall, of. cit. supra note 21, at 185. And fishing prerogatives were yielded even more slowly. Indeed, claims to such prerogatives continue to be made today, e.s.., the current dispute between Korea and Japan over the former country's claims.

29. See Lord Stowell in Le Louis, 2 Dods. 210, 243, 165 Eng. Rep. 1464, 1475 (Adm. 1817) : "all [nations] have an equal right to the uninterrupted use of the unappropriated parts of the ocean for their navigation." And Story, I., in The Mrarianns Flura, 24 U.S. (11 Wheat.) 1, 42 (1826): "Upon the ocean ... in time of peace, all possess an entire equality. It is the common highway of all, appropriated to the use of all; and no une can vindicate to himself a superior or exclusive prerogative there."

30. Point 2 of the "Fourteen Points" called for "[a]bsolute freedom of navigation upon the seas." 56 CoNG. Rec. 680 (1918). The 7th principle of the Atlantic Charter declared: "such a peace should enable all men to traverse the high seas and uceans without hindrance." Atlantic Charter, Aug. 14, 1941, 55 STAт. 1603, E.A.S. No. 236. 
"1. Freedom of navigation on the high seas, subject to the exclusive control, in the absence of a contrary convention, of the state whose flag the ship carries.

"2. Freedom of fisheries on the high seas, subject to the same conditions.

"3. Freedom to lay submarine cables on the high seas.

"4. Freedom of aerial movement above the high seas." 31

Freedom of the seas is an absolute freedom to use the high seas except, to the extent that international custom and treaties have modified it in orcler to meet the needs of a continually "smaller" and more dynamic international community. Thus, this freedom, not unlike our own constitutional guarantees of freedom, has not deteriorated into a total absence of restraint. ${ }^{32}$ "General" and "special" police powers over portions of the sea have come to be exercised by groups-sometimes all-of the maritime states. ${ }^{33}$ Among the general police powers exercised on the high seas in time of peace are the repression of piracy, self-defense, hot-pursuit, and the so-called "right of approach." Special police powers are created only by treaty, and are exercised in the relations between the signatories. Principal among these have been the slave trade prohibition, control of fisheries, and the supervision of submarine telecommunication cables.

In recent years, some unilateral encroachments upon the orthodox doctrine of freedom of the seas have been made by leading maritime powers with the tacit acceptance of others. A "contiguous zone" beyond the three-mile belt of territorial seas, for purposes of enforcement of customs, immigration, sanitation, or police regulations, appears to be fairly well recognized in the practice of states. ${ }^{34}$ And more recently, a number of states have claimed jurisdiction over the sea-bed and sub-soil of portions of the ocean adjacent to their coastin some cases a claim of millions of square miles. The legal justification for such claims is far from clear. Perhaps the classical pronouncement of this "doctrine of the continental shelf" was that of President Truman which stipulated that "the character as high seas of the waters above the continental shelf and the right to their free and unimpeded navigation are in no way thus affected." $" 35$

31. From the Resolution on "La Navigation en Haute Mer," aclopted by the Institute of International Law, found in [1927] 3 AN NUAIRE DE L'INSTITUT DE DroIT INTENNATIONAL. 339 (translated from the French).

32. "[L']absence de souveraineté territoriale n'est pas synonyme de carence du droit international." Raestad, La Chasse à la Baleite en Mer Libre, 2 Revue de Droit INTERNATIONAL 595, 634 (1928).

33. "General" and "special" police powers are used here in the same sense as they are employed by Gidel. "General" police powers may be exercised independently of treaty rights, and emerge "purely and simply" from custom; they are also "general" in the sense of not being limited to particular maritime zones. By contrast, "special police measures" exist only by virtue of treaties, and apply exclusively to the states which are parties to them. 1 Gidel, Le Droit International de La Mer 288-89 (1932).

34. See the article and commentary on the "Contiguous Zone" submitted by the U.N. International Law Commission. International Law Commission, Report, U.N. GenerAs. Assembly OfF. Rec., 8th Sess., Supp. No. 9, at 19 (Doc. No. A/2456) (1953).

35. $10 \mathrm{FED}$. REG. 12303 (1945). See also Argentine Declaration in 41 AM. J. INT'L I. Supp. 11 (1947). 
Bearing these exceptions in mind, the rule of law remains clear: no state can exercise sovereignty over the high seas in time of peace. ${ }^{30}$ The naturallaw theories which were used at first to support this principle have given way to a more pragmatic rationale: since the seas form a necessary means of transportation and communication among nations, their free use is indispensable to international trade and navigation. ${ }^{37}$

These general principles of law and the needs of the international community which they are designed to fulfill have a direct bearing on the nuclear experiments in the Pacific Proving Grounds. The establishment there of a 400,000 square mile "warning area" cannot be reconciled with freedom of navigation on the high seas and in the air space above the seas. The completely humanitarian purpose behind the establishment of such an area-that of warning ships and planes of a very real hazard to their safety-loses its force as a logical and legal justification when it is recalled that the hazard is artificially introduced. As one of the leading legal authorities in the United Kingdom, Earl Jowett, put the issue:

"I am entirely satisfied that the United States, in conducting these experiments, have taken every possible step open to them to avoid any possible danger. But the fact that the area which may be affected is so enormous at once brings this problem : that ships on their lawful occasions may be going through these waters, and you have no right under international law, I presume, to warn people off."38

No "general police power" can be found to justify fencing off from the maritime and air traffic of other nations hundreds of thousands of square miles of open sea and air space including waters forming "a useful route for international maritime traffic."39

Quarantining this area of high seas must, then, be based upon treaty arrangements, as an exercise of a form of "special police power." The only treaty" provision which has any relevance to the problem is Article 13 of the "Trusteeship Agreement for the Former Japanese Mandated Islands" which provides that the Administering Authority (the United States) may close any part of the Trust Territory at any time for reasons of security. ${ }^{10}$ Article 13 undoubted-

36. Whether viewed juridically as res unllius (a thing belonging to no one) or res communis (a thing belonging to everyone), the rule loses none of its efficacy for the purposes of the discussion here.

37. "The real reason for the freedom of the open sea is represented in the motive which led to the attack against maritime sovereignty, and in the purpose for which such attack was made-namely, the freedom of communication, and especially commeree, between the States which are severed by the sea." 1 Oppenheras, Intermatromar Law 54 (7thed., Lauterpacht 1948).

38. 186 H.L. Deb. (5th Ser.) S08-09 (1954). The Mlarquess of Salishury, representing the Foreign Office in these debates over the Pacific thermonuclear experiments, feit compelled to concede the point. Id. at 810 .

39. The phrase is borrowed from the opinion of the court in Corfu Channel Case, Judgment of April 9, 1949, [1949] I.C.J. Rep. 4, 28.

40. Although objected to as establishing a dangerous principle, Article 13 nonethe- 
ly authorizes the United States at any time to close off any or all of the Pacific islands in the Territory, including their territorial waters-approval by a major organ of the international community, the U.N. Security Council, having been given in advance by the terms of the Agreement. The atthority of Article 13 was exercised when the land and air space of Bikini and Eniwetok atolls "and the territorial waters adjacent thereto" were closed for the purposes of conducting atomic and thermonuclear experiments. ${ }^{41}$ But neither Article 13 nor any other provision of the Agreement states anything about the sea and air space beyond the territorial limits of the islands comprising the Trust Territory. The centuries-old principles of freedom of navigation on the open seas and freedom of the air space above these seas remain untouched and undiluted. The conclusion is thus inescapable that the warning zone announced by the AEC in December 1947 and enlarged in May 1953 and April 1954 can find no authorization in any treaty.

It goes without saying that the setting up of so vast a warning zone was prompted by a desire on the part of the United States to protect the lives and property of "intruders." But humanitarian ends have led the United States deeper and deeper into this legal dilemma : the greater the degree of precaution, the greater the interference with freedom of navigation on the high seas. The very nature of these experiments is such that, to the extent that adequate safety measures are taken, traditional and universally accepted rules of international law must be violated.

Thermonuclear tests pose also a practical dilemma. The protection of persons and ships from the fallout of radioactive ash militates in favor of expanding the warning area. But the more the area is increased, the more difficult it becomes to police it adequately. Admiral Strauss, chairman of the AEC, has stated that there have been "many instances where accidents or near accidents have resulted from inadvertent trespass in such warning areas. The very size of them makes it impossible to fence or police them."42

Thus, expansion of the warning area-despite the humanitarian intentions which motivate it-piles contradiction upon contradiction.

less was adopted by the unanimous vote of the U.N. Security Council at its 124th meeting, April 2, 1947. Its full text reads: "The provisions of Articles 87 and 88 of the Charter shall be applicable to the Trust Territory, provided that the Administering Authority may determine the extent of their applicability to any areas which may from time to time be specified by it as closed for security reasons." Article 87 of the Charter gives the Trusteeship Council the right, inter alia, to make periodic visits to the trust territory. U.N. Article 88 imposes a duty on the administering authority to make an anumal report to the General Assembly on the "political, economic, social and educational advancement" of the inhabitants of the trust territory in response to a questionnaire prepared by the Trusteeship Council.

41. See letters from the Representative of the United States directed to the United Nations, informing the organization formally of the closing of these atolls. U.N. SFcuwrY Council Off. Rec., 2d year, Supp. No. 20, Annex 46, at 169 (Doc. No. S/613) (1947); U.N. Doc. No. S/2978 (1953).

42. From his statement to the press of March 31, 1954, inserted by Rep. Sterling Cole into 100 Cong. Rec., 4234 (daily ed. April 2, 1954). 


\section{Radioactivity: Its INTernational LAN Asiects \\ The Facts}

The exact extent to which the thermonuclear experiments of March-April 1954 contaminated the waters and the air space within, as well as without, the warning area is not completely clear. What is clear, however, are the serious questions of law raised by the injury to men, to ships, and to fish caused by the fallout of radioactive ash from the explosions. And from the mushroom of reports and allegations following the March 1st explosion, a number of fairly indisputable facts emerge.

The thermonuclear detonation of March 1, 1954, exposed 236 Marshallese and twenty-eight United States personnel to radiation when an unexpected shift in the winds placed the islands of Rongelap, Rongerik, and Uterik in the path of the fallout. ${ }^{43}$ The AEC subsequently reported that the atmosphere above " 7,000 square miles of territory downwind from the point of burst was so contaminated" from radioactive fallout that survival in the area would have depended upon "prompt evacuation of the area or upon taking shelter and other protective measures."44

On March 14, 1954, the Japanese fishing boat Fukuryu Maru reached port with both the ship and its catch radioactive. The log of the vessel showed that it had been approximately eighty miles off Bikini when the March Ist explosion occurred. ${ }^{45}$ All twenty-three crew members were suffering from exposure to radiation and were immediately hospitalized, five being placed on the danger list. ${ }^{46}$ On September 23, 1954, Aikichi Kuboyama died from radiation siclness, while the other twenty-two crewmen continued to undergo treatment in Tokyo hospitals. ${ }^{47}$ In June five crewmen of a Japanese freighter which had passed within 1,200 miles of the bomb-test area were hospitalized with radiztion sickness, and were reported to be "gradually recovering." 48

43. Announcement by the AEC, N.Y. Times, March 12, 1954, p. 1, col. 1. Not all of the injuries resulted directly from the fallout. The inhabitants of the islands affected hy the fallout apparently had not been warned about the explosions and did not know that the water on these islands had become dangerous to drink. See U.N. Doc. No. T/C.2/SR. 197 , at 5 (1954).

According to Sen. Mike Mansfield (Montana), the Miarshallese were still suffering from the various symptoms of radiation sickness months after the March 1st explosion. 100 Cong. Rec., 7681 (daily ed. June 14, 1954). See also Petition from the Mlarshallese People Concerning the Pacific Islands, U.N. Doc. No. T/Pet.10/28 (1954). These contentions contrast sharply with the statement of Admiral Strauss: "The 236 natives appeared to me to be well and happy." Statement cited note 42 supra at 4234 .

44. N.Y. Times, Feb. 16, 1955, p. 18, col. 4, para. 23.

45. N.Y. Times, March 17, 1954, p. 9, col. 4. Arnold, Effects of the Recent Bonib Tests on Human Beings, 10 Burl. Atosr. Scientists 347 (1954), states that it is now agreed that the ship was "definitely outside the 30,000 square mile prohibited zone, and 72 miles from the test site, at the time of the first test on MIarch 1." But cf. the opinion of Admiral Strauss that the ship must have been "well within" the warning area. Statement cited supra note 42 , at 4234 .

46. N.Y. Times, March 17, 1954, p. 1, col. 5, p. 9, col. 3.

47. N.Y. Times, Sept. 24, 1954, p. 10, col. 3.

48. N.Y. Times, June 5, 1954, p. 2, col. 6 . 
In addition to the injuries to fishermen, the Japanese fishing industry itself was seriously affected. Over four thousand pounds of the Fukuryu Maru's tuna catch were ordered buried by Japanese sanitation authorities. ${ }^{10} \Lambda$ nother fishing vessel, the Shunyo Maru, was found to be radioactive and its catch contaminated on its arrival in Japan. On March 1st, it had been some 1,000 miles from Bikini; the nearest it ever approached the test aren was 200 miles, six days after the explosion. ${ }^{50}$ The Shoho Maru and Kaifuku Maru arrived in port on April 8,1954, with cargoes of radioactive tuna, but none of their crew members were injured. ${ }^{51}$ The captains of both vessels said they had pursued courses clearly outside the Bikini-Eniwetok test area. Throughout $A$ pril and May reports emanated from Japan of further radioactivity in ships and their catch-ships whose closest distance to Bikini ranged from 1,000 to 2,000 miles. Of the 33,600 tons of fish from 905 boats inspected through June 20, 195* 135 tons from 77 boats were condemned. ${ }^{52}$ And Professor Takajiro Nori of Tokyo University declared on October 6,1954 , that the number of radioactive fish caught was increasing. In March, nearly all contaminated fish were caught in or near the Bikini test area. But by April, large numbers were found off Formosa, and in June radioactive fish were caught off the Japanese coast. ${ }^{\text {ta }}$

This series of events could not fail to produce hardship for the Japanese fishing industry-a very important segment of that nation's economy, provicling the main source of protein in the Japanese diet. Significant quantities of fish were destroyed. What was not destroyed people were afraid to eat. Lxport of fish became increasingly difficult, for importers feared that consumer resistance in their countries would be strong. On April 1, 1954, the Japanese Foreign Office formally requested the United States to call off its Pacific tests from November through March, the best fishing season. It also asked for prior notification of any future tests and a relaxation of the restricted area in the Marshalls to permit fishing when no tests were scheduled. ${ }^{54}$ The reqtiest for advance notification was formally refused. ${ }^{65}$

Shortly after the Fukuryu Maru incident, the United States announced its readiness to make monetary compensation for personal and property damages sustained by Japanese nationals. ${ }^{50}$ After months of negotiation, the matter

49. N.Y. Times, March 17, 1954, p. 1, col. 5 , p. 9, col. 4.

50. Manchester Guardian Weekly, March 25, 1954, p. 2, col. 3.

51. N.Y. Herald Tribune, April 9, 1954, p. 9, col. 5. About one-third of the thirtyfive tons of tuna fish caught by the Kaifuku Marn were ordered confiscated because it registered a radioactive count of 100 impulses a minute. Six fish of the S/hoho Maru registered a count of 60-1300 impulses a minute.

52. Arnold, Effects of the Recent Bomb Tests on Htman Beings, 10 BuLl. Arom. Screntists 347-48 (1954): "The criterion used was a counting rate of 100 counts per minute four inches from the body of the fish, on a Geiger tube whose normal background was $20-30$ counts per minute."

53. N.Y. Times, Oct. 7, 1954, p. 25, col. 4.

54. N.Y. Times, April 1, 1954, p. 26, col. 1.

55. N.Y. Times, July 10, 1954, p. 5, col. 3.

56. See statement of Admiral Strauss, 100 Cong. Rec. 4234 (daily ed. April 2, 1954). 
was settled on January 4,1955, through an exchange of notes between the Japanese Foreign Minister and the United States Ambassador to Japan."5i The United States tendered to the Government of Japan "ex gralia" and "without reference to the question of legal liability, the sum of two million dollars for purposes of compensation for the injuries or damages sustained" by Japanese nationals as a result of the thermonuclear tests. The sum was tendered and accepted "in full settlement of any and all claims" against the United States, "or its agents, nationals or juridical entities."

\section{The Law}

The emergence of nuclear energy as an instrument of warfare has brought with it legal questions of the utmost gravity. There is no consensus of authoritative legal opinion as to the compatibility of the employment of weapons of such incalculable ${ }^{58}$ destructive power with the laws of war. ${ }^{\text {s9 }}$ And even the

57. Notes Regarding Bikini Claims, Dep't of State Press Release No. 6, Jan. 4, 1955.

58. The term "incalculable" is used advisedly. Comprehensive and evact scientific analysis of the direct and indirect physical effects-such things as sterility in both men and women, genetic mutations, cataracts, susceptibility to secondary bacterial infectionslet alone the psychological effects, produced by the atomic bombing of Hiroshima (August 6,1945 ) and Nagasaki (August 9, 1945) upon the Japanese who managed to survive appears to be no longer possible. See Los Alasios Scientific Lacoriton;, The Erfects of Atonic Weapons 339-65 and passin (1950) ; Grobaran, Our Atosnc Heratage 62-81 (1951). And "in the space of time from Hiroshima to the present the incredible power of the uranium bomb has been dwarfed almost a thousand-fold by the awesome force of the hydrogen weapon." Sawyer, The H-Bomb Chronology, 10 BuLn. Aroxr. Scre:strsts 287, 300 (1954). Furthermore, the series of explosions since World War II has given rise to serious concern among scientists over the dispersion of radioactive products and their immediate, delayed, and remote effects. This dispersion, according to an eminent geneticist, will unquestionably produce genetic mutations the overwhelming majority of which are deleterious and likely to produce a significant rise in defective individuals in succeeding generations. Sturtevant, Social Implications of the Genelics of Man, 120 Scre:ice 405-07 (1954). Making every effort to be conservative- "the true value could possibly be 100 times greater"-Sturtevant calculates that 1,800 of the $90,000,000$ children born in the world last year were adversely affected by radiation from thermonuclear tests. Quoted in Plumb, Science in Review, N.Y. Times, Jan. 16, 1955, $\$ 4$, p. 11, cols. 6-7. Calling attention to the atomic experiments which the Great Powers have carried on in recent years, Edgar D. Adrian, English physiologist and Nobel Prize winner, declared: "We must face the possibility that repeated atomic explosions will lead to a degree of general radioactivity which no one can tolerate or escape" N.Y. Times, Sept. 2, 1954, p. 23, col. \&. Another Nobel Prize winner, the French physicist Prince Louis de Broglie, writes that the complexity of physical phenomena produced by the hydrogen bomb explosions to date, has already removed the possibility of accurately calculating their effects. N.Y. Times, Nov. 23, 1954, p. 5, col. 4. The Federation of Amorican Scientists recently asked the U.N. to study the problem of radioactive contamination of the world's atmosphere irom bomb tests, to obtain scientific data on the intensity of radiation produced, and to establish the "danger threshold" to human beings, physically and genetically, from radiation. N.Y. Times, March 7, 1955, p. 1, col. 3, p. 12, cols. 4-8.

59. A reasoned and balanced discussion of this problem may be found in 2 Orpeniners, INTERNATIONAL LAw 347-52 (7th ed., Lauterpacht 1952). For a statement arguing the 
testing of these devices presents legal problems of perhaps less magnitude, but of far greater immediacy. The newness of atomic weapons makes an analysis of these problems on the basis of relevant rules of international law a difficult task. There are no general principles on all fours with the issue, nor are there treaty provisions setting forth such clear "Thou shalt not's" as to leave no room for doubt with regard to conducting thermonuclear experiments.

But this is not to say that thermonuclear tests are beyond the scope of international law at its present stage of development. To begin with, the law of fisheries on the high seas is applicable. Secondly, the radioactivation of extensive areas of seas and air space may by analogy fall within the rules which are emerging under the inchoate doctrine of "pollution" in international law. And finally, the "Trusteeship Agreement for the Former Japanese Mandated Islands" contains a number of provisions which impose rather specific responsibilities upon the United States, offering still another frame of reference within which the legal character of the tests may be measured.

\section{The Law of Fisheries}

The cordoning off of a vast area of the Pacific for extended periods combined with radioactive fallout from the test explosions seriously impaired and interrupted the fishing industry of Japan. That this interruption is a violation of the international law rule of freedom of fisheries on the high seas is apparent from the broad terms in which that doctrine has been cast, admitting of qualification only by restrictions imposed by treaty: $:^{(00}$

"All states are entitled to claim for their nationals, and their nationals are entitled to claim from other states... the right to utilize the high seas with their private vessels for any legitimate purpose, such as . . . fishing ... except in so far as these rights have been surrendered by treaty agreements." 61

Similarly, the United Nations International Law Commission has asserted that "it may be contrary to the very principle of freedom of the seas to encourage or permit action which amounts to an abuse of a right and which is apt

illegality of the use of such weapons, see SpAight, AIR Power AND WAR RIGHits 273-77 (3d ed. 1947). Fenwick speaks of the "doubtful legality of the atomic bomb." FENwick, International Law 559 (3d ed. 1948). See, also speech by W.H. Moore, General Secretary of the International Law Association, N.Y. Times, Aug. 10, 1954, p. 9, col. 2. For the contrary view see Stimson, The Decision to Use the Atomic Bomb, 194 Hanpers's Mag. 97 (1947); Stowell, The Lazes of War and the Atomic Bomb, 39 Arr. J. InT'L L. 784 (1945) ; Baxter, The Role of Law in Modern War, 47 Proc. Am. Soc'Y INT'L L. 90 (1953), and Discussion, id. at 119.

60. See para. 2 in text at note 31 supra.

61. Potter, The Freedons of the Seas 101 (1924). According to Gidel: "The idea which underlies the law of the sea is the freedom of lawful and normal utilization of the maritime space; all unnecessary restrictions upon this frcedom should be avoided." 3 Givit, Le Droit International Public de la Mer 674 (1934) (translated from the French). See also United States v. California, 332 U.S. 19, 35 (1947). 
to destroy the natural resources whose preservation and common use have been one of the main objects of the doctrine of the freedom of the sea."62

Moreover, states have a clear duty under international law to prevent activities, particularly those of its own agencies, which endanger lives or injure property of nationals of other states in time of peace. Some authorities explain this duty to prevent injury by the emerging and still somewhat controversial doctrine of "abuse of rights": a state is liable for indenmity when it exploits a right it possesses under international law "in such a way as to inflict upon another State an injury which cannot be justified by a legitimate consideration of its own advantage." 63

IThether viewed as a violation of the law of fisheries or an abuse of right, the conclusion remains the same: the interference with the interests of other nations in fishing the high seas caused by the hydrogen bomb tests incurs the responsibility of the United States for resulting damages.

\section{The Law of Pollution}

The injurious effects of the thermonuclear explosions may be viewed also within the juridical context of the responsibility of states to prevent pollution of international waters and air space. To date, concern over the problem of pollution of international waters has been restricted almost exclusively to pollution from the discharge of oil by ships. ${ }^{\text {gt }}$ And, while international bodies have given the matter increasing attention over the past few decades, ${ }^{60}$ and various states have passed legislation aimed at ameliorating its wasteful and unsanitary after-effects, ${ }^{66}$ the nations thus far have been unsuccessful in their efforts to regulate pollution by general treaty or convention.

Nevertheless, judicial tribunals have used general principles of law and equity to resolve disputes concerning pollution. Some of the leading cases on

62. International Law Commission, Report, U.N. General Assearbly Off. Rec., 8th Sess., Supp. No. 9, at 18 (Doc. No. A/2456) (1953).

63. See 1 Oppenheta, Interatitonal Law 313 (7th ed., Lauterpacht 1948). According to the U.N. International Law Commission, "the prohibition of abuse of rights is supported by judicial and other authority .... A State which arbitrarily and without good reason, in rigid reliance upon the principle of freedom of the scas, declines to play its part in measures reasonably necessary for the preservation of valuable, or uften essential, resources from waste and exploitation, abuses a right conferred upun it by international law:" International Law Commission, supra note 62, at 18 .

64. See, c.g., 1 Gider, op. cit. sutpra note 61, at $4 \$ 0-84$; Higarss \& Colossos, Tue INTERNational Law OF THE SeA $291-93$ (2d ed. 1951).

65. See Intervational Law Association, Rep't of 33d Confenence, 1924, pp. $336-42$ (1925); Washington Prelinimary Conference on Oll Polletion of Namgaele Waters (1926) ; Organization for Communications and Trassit, Polletion of tar Sea by Oil (League of Nattons Pub. No. 1935.VIII.5) (1935). More recently, see the discussions which have taken place in the Transport and Communications Commissiun of the U.N. Economic and Social Council, particularly the report by the Secretary-General, Pollution of Sea Water, U.N. Doc. No. E/CN.2/134 (1952).

66. See, e.g., Oil in Navigable Waters Act, 1922, 12-13 Geo. 5, c. 39; Oil Pollution Act, 43 STAr. 604 (1924), 33 U.S.C. §§ $431-37$ (1952). 
the subject are decisions of the United States Supreme Court in disputes between states of the union. In such cases the Court has established the following rule: a state may be enjoined from conduct which pollutes interstate waters, or waters flowing into a neighboring state, if it can be shown that the pollution and its effects are of sufficiently "serious magnittude."67

This same "serious magnitude" test was recognized and applied as al rule of international law by an arbitral tribunal in the Trail Swelter Case. ${ }^{\text {"s }}$ The United States received an indemnity award of $\$ 78,000$ for damages to land, crops, and trees in the state of Washington from sulphur dioxide fumes emitted by a Canadian smelting company. The tribunal ruled that "no State has the right to use or permit the use of its territory in such a manner as to cause injury by fumes in or to the territory of another or the properties or persons therein, when the case is of serious consequence and the injury is established by clear and convincing evidence."60 If such a restriction is imposed upon the use by a state of its own territory, it would seem to apply with even greater force to the use of a Trust Territory-a land which is being held in "trust" under "a relation of service and delegation wholly incompatible with any exclusiveness of rights of sovereignty on the part of the State concerned."70 And if sulphur dioxide fumes giving rise to damages of $\$ 78,000$ is a "case of serious consequence," how much more so is the radioactivation of thousands of square miles of high seas and the air space above these seas. Surely the rule of Trail Smelter applies directly to serious injury to persons and property on the high seas, since "a ship on the high seas is assimilated to the territory of the State the flag of which it flies."'71 It is somewhat less clear whether the Trail Smelter rule may be carried beyond injury to foreign nationals and foreign territory, and applied to the contamination of high seas fisheries, except perhaps by invoking a res communis theory with respect to the natural resources of the seas.

67. New Jersey v. City of New York, 283 U.S. 473 (1931) ; New York v. New Jersey, 256 U.S. 296 (1921). Cf. Missouri v. Illinois, 200 U.S. 496 (1906) (Court refused to enjoin defendants from emptying sewage into tributary of Missouri River because it was not shown pollution was "of serious magnitude"). The force of such interstate cases as precedent in international law was recognized in Trail Smelter Case, Award of April 16, 1938, and March 11, 1941, 3 U.N. Rep. InT'L ARBitral AwArds 1905, 1964: "it is reasonable to follow by analogy, in international cases, precedents established by that court in dealing with controversies between States of the Union or with other controversies concerning the quasi-sovereign rights of such States, where no contrary rule prevails in international law and no reason for rejecting such precedents can be adduced from the limitations of sovereignty inherent in the Constitution of the United States."

68. Award of April 16, 1938, and March 11, 1941, 3 U.N. REP. INT'L ARutrRaL AwARDS 1905.

69. Trail Smelter Case, Award of April 16, 1938, and March 11, 1941, 3 U.N. Rep. INT'L ARBITRAL AwARdS 1905, 1965 (emphasis added).

70. 1 Oppenheim, International Law 215 (7th ed., Lauterpacht 1952).

71. The Case of the S.S. "Lotus," P.C.I.J. Ser. A., No. 10, p. 25 (1927). 
Pollution which causes destruction of the high seas' natural resources has been condemned by authoritative international legal opinion. Thus, the Institute of International Law dealt with the problem at its 1937 conference, and passed a resolution calling upon all interested governments to study ways to eliminate practices injurious (dommageables) to marine life, such as the uncontrolled discharge of oil, bilge-water, rubbish, or other noxious (misibles) substances. ${ }^{72}$ The resolution concluded:

"In any case, the Institute is of the opinion that a State fails its international responsibilities if it neglects to take appropriate measures to prevent practices which, in the light of science, are manifestly contrary to rational exploitation and protection of the riches of the sea."73

Nevertheless, without specific treaty arrangements, and in the absence of international decisions squarely in point, the duty of states under international law to prevent pollution of international waters is as yet an inchoate one. The Supreme Court pollution cases and the Trail Smeltcr Case provide most helpful analogies. Bilateral treaties which deal with the problem (and there are very few of them) offer some guidance. ${ }^{74}$ But there remains a need for the members of the international community-whether through the efforts of the U.N. Transport and Communications Commission, ${ }^{75}$ or through the work of the Inter-Governmental Maritime Consultative Organization-to draw up a convention to regulate pollution of international waters. In the absence of a general convention of this type, binding upon all maritime states, the requirements of decisional and treaty law, with regard to the contamination of international waters and air space, are perhaps less clear than those of justice and equity.

\section{The Trusteeship Agreenent}

Injury to health and property caused by radioactivity from the thermonuclear explosions are proscribed also by treaties to which the United States is a party-The United Nations Charter and the "Trusteeship Agreement for the Former Japanese Mandated Islands." The chapters of the U.N. Charter dealing with Non-Self-Governing Territories ${ }^{70}$ and the International Trustee-

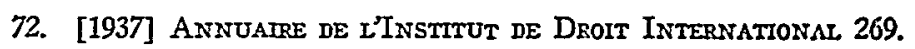

73. Id. at 271 (translated from the French).

74. See, e.g., Article IV of the Convention of Jan. 11, 1909, between Great Britain and the United States, dealing with the boundary waters between Canada and the United States: "the waters herein defined as boundary waters and waters flowing across the boundary shall not be polluted on either side to the injury of health or property on the other." 36 Stat. 2448,2450 , T.S. No. 548.

75. This Commission has already concerned itself with the question of the pollution of sea water by radioactive waste from atomic fuel used by ships. U.N. Doc No. E/CN. $2 / 100$ (1951).

76. U.N. CEARTER c. XI. Called by Ralph Bunche an "international charter of colonial 
ship System ${ }^{77}$ are not easily reconciled with conducting hazardous atomic experiments in the Marshall Islands. Article 73 establishes "the principle that the interests of the inhabitants of these territories are paramount." It speaks also of the "sacred trust" of the Administering Authority to promote the "wellbeing" of the territories' inhabitants and imposes an obligation "to ensure . . . their protection against abuses." 78

Article 6 of the Trusteeship Agreement describes even more specifically the responsibilities of the United States as Administering Authority. The $\Lambda \mathrm{d}-$ ministering Authority must promote the "economic advancement and selfsufficiency of the inhabitants"- a goal which is to be realized by encouraging "the development of fisheries, agriculture, and industries" and by protecting the inhabitants against the "loss of their lands and resources."79 Article $\sigma$ also requires the Administering Authority to "protect the health of the inhabitants." 80 These duties, it should be noted, are unqualified imperatives. They are preceded by the word "shall" and are not diluted by the phrase "subject to the requirements of security" which qualifies several other key articles of the Agreement. ${ }^{81}$

Evacuation of the Marshallese from their home islands and injury to their health and fishing industry seem to contravene the treaty obligations assumed by the United States despite the broad powers granted it as Administering Authority. Under the provisions of Article 5 of the Trusteeship Agreement. the United States does have the right to station armed forces and to erect fortifications in the territory ${ }^{82}$-it having been designated as strategic. Equally unquestionable is the power of the Administering Authority under Article 1,3 to close any area of the territory "for security reasons." 33 But neither article can be interpreted as derogating from the obligations which Article 73 of the U.N. Charter and Article 6 of the Trusteeship Agreement place upon the Administering Authority. Article 13 of the Agreement stipulates that Articles 87 and $88^{84}$ of the Charter shall not apply to the "closed areas," but it says

administration." Bunche, Trustecslip and Non-Self-Governing Territories in the Charler of the United Nations, 13 Dep'T STATE Bull. 1037, 1040 (1945).

77. U.N. CharTER c. XII.

78. During the committee discussion at the U.N. Conference on International Organization (San Francisco, 1945), the Netherlands Representative asked for assurance that the three most notorious forms of "abuse" would be provided for: (1) failure to protect their land, particularly arable land, (2) forced labor, and (3) racial discrimination. In reply, the U.S. Representative stated that he would regard it as clear that "the abuses you refer to are included in the abuses against which the people concerned are to be protected and the obligation referred to in paragraph 1 [ultimately incorporated into the Charter as Art. 73] covers this situation." See Doc. No. 1090, II/4/43, 10 U.N. Cons. INT'L OrG. Docs. 563-64 (1945) ; Doc. No. 1115 II/4/44(1) (a), 10 id. at 619.

79. Trusteeship Agreement, art. 6(2).

80. TRUSTEESHIP AGREEMENT, art. 6(3).

81. This qualifying phrase appears in Articles 7 and $8(1)$.

82. Trusteeship Agreement, art. 5(1), (2).

83. TRUSTEESHip AgREEMENT, art. 13.

84. See note 40 supra. 
nothing about Article 73. Article 6 of the Agreement stands unqualified by security considerations. ${ }^{85}$

Thus, the legal problem posed by thermonuclear experiments in the Marshall Islands territory goes beyond caring for physical injuries already suffered by the Marshallese. The Administering Authority has a positive duty to take all possible steps to prevent recurrence of such injuries. ${ }^{80}$ The duties imposed by the U.N. Charter and the Trusteeship Agreement produce a dilemma not unlike that created by the doctrine of freedom of navigation: the greater the precautions taken by the Administering Authority to protect the health of the Marshallese people, the greater the infringement of the rights guaranteed them by the Charter and Trusteeship Agreement. Removing them from the zone of danger ${ }^{87}$ means removing them from their land in violation of Article 73 of the Charter and Article 6 of the Trusteeship Agreement. Ensuring their continued safety also means depriving them of fishing grounds for months at a time, contrary to the requirements of Article 6 of the Trusteeship Agreement that the Administering Authority shall promote the economic advancement and self-sufficiency of the inhabitants by encouraging the development of fisheries and by protecting the inhabitants against loss of their natural resources. ${ }^{88}$

The conclusion thus becomes inescapable that the geographic quarantine and the physical consequences of thermonuclear tests in the Pacific Proving Grounds are at variance with solemn treaty obligations of the United States under the U.N. Charter and the Trusteeship Agreement.

85. See text at note 81 sipra.

86. Accidents or near accidents are bound to occur because of "inadvertent trespass" into the warning areas whose enormous size makes it impossible to police them adequate1y. Statement of Admiral Strauss, 100 Cong. Rec 4234 (daily ed. April 2, 1954). Furthermore, injuries such as those suffered by 236 Marshallese when "the wind failed to follow the predictions but shifted south," ibid., are likely to recur, since wind direction and shifts can never be predicted with sufficient accuracy to insure the safety of inhabitants of the area.

87. "Land means a great deal to the Marshallese. It means more than just a place where you can plant your food crops and build your houses; or a place where you can bury your dead. It is the very life of the people. Talse away their land and their spirits go also.... The Japanese had taken away the best portions of the following atolls; Jaluit, Kwajalein, Enewetak [sic], Mille, Maloelap and Wotje to be fortified as part of their preparation for the last war, World War II. So far, only Imedj Island on Jaluit Atoll has been returned to its former owners. For security reasons, Kwajalein Island is being kept for the military use. Bikini and Eniwetak [sic] were taken away for Atomic bomb tests and their inhabitants were moved to Kili Island and Ujelang Atoll respectively. Because Rongelab and Uterik are now radioactive, their inhabitants are being kept on Kwajalein for an indeterminate length of time." Petition from the Marshallese Pcople Concenting the Pacific Islands, U.N. Doc. No. T/Pet.10/2S (1954).

SS. The Bikini people offer a good case in point. On Bikini their primary accupation was fishing. They have since been removed to Kili Island where there is no fishing for seven months of the year when high surf makes it almost impossible to land on the island. Kili is now called "the island of hungry people." N.Y. Times, June 28,1954, p. 3, col. 5. 


\section{CONCLUSION}

"World order, in the long run, depends, not on men, but upon law, law which embodies eternal principles of justice and morality."

$$
\text { -John Foster Dulles } 80
$$

The United States, as a leading state in the contemporary power struggle, has prided itself on its adherence to the fundamental principles and usages of international law. It has long been in the forefront of those world powers who insist on strict observance of treaty obligations. This cornerstone of American foreign policy has been a source of great strength and prestige for this country among the peoples of the world, ${ }^{00}$ and, at the same time, an ideological springboard for attack against our competitors in the so-called war for men's minds. It seems clear that the United States cannot maintain this enviable position in the face of the facts surrounding its thermonuclear tests in the Pacific. Nor, so long as its own hands are unclean, can it hope to convince other governments and peoples of the sincerity of its concern over Soviet and Chinese violations of international law.

The United States has no present intention of halting the Pacific experiments, ${ }^{91}$ although it has pledged itself to do everything possible to prevent further injuries or damage. ${ }^{92}$ The primary official justification for continuing the tests appears to be the politico-military argument that "no one could reasonably contend that the Soviet should be the only nation to conduct nuclear experiments." 93

It may be that the nature of the world struggle precludes the possibility of the discontinuation of thermonuclear experiments by the United States and the Soviet Union. Such a desirable state of things could perhaps be brought about only by means of a treaty barring the production of thermonuclear weapons with provisions for international supervision and other safeguards. But assuming that experiments will go on, this nation still confronts the task of carrying them out in a manner compatible with the basic general tenets of international law and with the specific provisions of the United Nations Charter and the Trusteeship Agreement.

89. Dulles, The Challenge of Our Time: Peace with Justice, 39 A.B.A.J. 1063, 1066 (1953).

90. For a contrary view, see the attack by George Kennan on our "legalistic-moralistic approach to international problems." Kennan, American Diplomacy, 1900-1950 c. VI and passin (1951).

91. See statement of Admiral Strauss, N.Y. Times, Sept. 10, 1954, p. 1, col. 3. Sce also statements of Frank E. Midciff, U.S. High Commissioner of the Pacific Islands, and Mason Sears, U.S. Representative on the U.N. Trusteeship Council, N.Y. Times, July \&, 1954, p. 5, col. 1 .

92. See, e.g., statement by the United States Representative at the United Nations, Henry Cabot Lodge, concerning the Marshallese Petition on the thermonuclear tests. N.Y. Times, May 15, 1954, p. 10, cols. 5-6.

93. Statement of Mason Sears before the U.N. Trusteeship Council, N.Y. Times, July 8, 1954, p. 5, col. 1. When the Syrian Representative on the Trusteeship Council asked Mr. Sears how the nuclear tests could be reconciled with U.S. obligations under the U.N. Charter and the Trusteeship Agreement, Mr. Sears retorted (in somewhat uin- 
The conflicting demands of military preparedness and international law can be satisfied only by discontinuing the tests in the Pacific Proving Grounds, and by conducting them instead within the continental limits of the United States, or Alaska, or somewhere within the Arctic Region in the "sector" north of Alaska, or-by agreement with the Canadian Government-in the Canadian "sector." Any one of these alternatives would remove most, if not all, of the legal objections to the United States' thermonuclear experiments as they are currently conducted.

Selecting a proving ground within continental United States unquestionably would be no small undertaking. It would necessitate evacuation of the population from exceedingly large areas-conceivably an entire state or group of states-or, in the case of Alaska, a great part or all of the vast territory. Nevertheless, it seems eminently reasonable and just that we, who are undertaking to produce a weapon of such destructive power, are the people who should make the sacrifices which may be necessary for perfecting it. We should be prepared to run the risks of injury to health and property ourselves. If we are not prepared to expose ourselves to these hazards, a forliori we have no right to expose other peoples to them in order to protect our citizens. Both morals and logic dictate that the risk of thermonuclear tests should be borne by the state benefiting from them. ${ }^{95}$

The Arctic region offers the advantages of remoteness and lack of population. On the other hand, it may be (and on this point the writer can malse no claim to knowledge) that the atmospheric and terrain conditions of the Arctic would make experiments impracticable.90

The conclusion remains clear: the laws of humanity suggest and the law of nations requires immediate cessation of the thermonuclear experiments in the Pacific Proving Grounds.

diplomatic fashion): "This is a kind of silly question. The Syrian Representative knows exactly what is going on in the world today, and that we can't stop as long as the Russians don't" N.Y. Times, July 10, 1954, p. 5, col. 3.

94. "Sector" is the technical international law term referring to the not yet fully accepted juridical basis for claims to regions surrounding the North Pole. Under this principle, claims of sovereignty over Arctic territories are defined by the coastlines of states contiguous to the polar region, with meridians drawn northward from the extreme points of these coastlines to their apex at the Pole. Thus, Arctic "pie-sectors" have been claimed and occupied by the U.S.S.R, Canada, Denmark (through Greenland), Norway, and the United States (through Alaska). Fenwrick, Internatiusus. Law 354 (3d ed. 1948).

95. For a similar conclusion, prompted by scientific and moral considerations, see Arnold, Effects of the Recent Bomb Tests on Human Beings, 10 Bunt. Arosr. SeIEstists 347,348 (1954).

96. Reports from Japan have indicated that the U.S.S.R. has been conducting its uwn thermonuclear experiments on Wrangel Island in the Soviet Arctic sector. N.Y. Times, Sept. 23, 1954, p. 4, col. 3. There have been other reports of the use of Cape Chaplin in northeastern Siberia as a Soviet proving ground. N.Y. Times, Aug. 17, 1954, p. 16, col. 4. The United States has denied reports that the Antarctic was being explored by this country with a view toward its suitability for H-bomb experiments. N.Y. Times, Nov. 12, 1954, p. 8 , col. 6 . 